J. Clin. Chem. Clin. Biochem.

Vol. 28, 1990, pp. 113-118

(C) 1990 Walter de Gruyter \& Co. Berlin - New York

\title{
Investigations on Red Cell Size Distribution Histograms in Subjects Treated by Maintenance Haemodialysis
}

\author{
By P. C. Bartels
}

Department of Clinical Chemistry and Haematology, Medical Centre Alkmaar, The Netherlands

\section{P. W. Helleman}

Department of Haematology, Laboratory of Clinical Chemistry, National Institute of Public Health and Environmental Hygiene, Bilthoven and

J. B. J. Soons

Department of Clinical Chemistry, Faculty of Pharmacy, State University Utrecht, Utrecht

(Received August 3/October 10, 1989)

Summary: In forty-nine subjects on maintenance haemodialysis quantitative information with respect to changes in the erythron was derived from the red blood cell size distribution histogram. Increased values for the fraction of microcytes were observed in seventeen subjects, whereas in three subjects increased fractions of macrocytes were established. Both fractions were found to be increased simultaneously in only one subject. In the case of normal mean corpuscular volume (MCV) values, the fractions of microcytes were shown to be increased in four male and three female subjects. In contrast, $\mathrm{MCV}$ values were increased in four male subjects while the fractions of macrocytes did not exceed the reference range.

Several causes which may give rise to abnormalities in red blood cell size distribution histograms in subjects treated by haemodialysis are discussed. From the interpretation of results for serum ferritin concentration, serum iron concentration, total iron binding capacity, and iron saturation percentage it is difficult to establish unequivocally whether the iron supply to the patient is appropriate.

\section{Introduction}

In subjects on chronic haemodialysis, therapeutic intervention would be more successful if factors which may contribute to the failure of erythropoiesis were better understood. In several conditions, red blood cell indices may be within the reference range, whereas microcytic red blood cells are increased (1). In subjects

\footnotetext{
1) Abbreviations

$\mathrm{Hb} \quad=$ haemoglobin concentration

$\mathrm{MCV}=$ mean corpuscular red cell volume

$\mathrm{MCH}=$ mean corpuscular red cell haemoglobin content

$\mathrm{MCHC}=$ mean corpuscular red cell haemoglobin concentration

$\mathrm{ADW}_{0.5}=$ absolute distribution width at half peak height
}

treated by maintenance haemodialysis, increased proportions of microcytic red blood cells may be found due to iron deficiency or aluminium intoxication (2). Occasionally an increased proportion of macrocytic red blood cells can be observed (3). Iron deficiency may frequently prevail as a complication of chronic haemodialysis (4). The main causes are blood loss on the dialysis membrane and bleeding secondary to uraemic gastroenteritis and platelet dysfunction. From the generally used laboratory tests to establish iron deficiency, the determination of the serum ferritin concentration is considered to be the most suitable when checked regularly, e. g. at monthly or bimonthly intervals $(3,5)$. Maintaining the serum ferritin con- 
centration within certain limits by iron supplementation or treatment with desferrioxamine would minimize the risk of iron deficiency or haemosiderosis $(6-8)$.

Drawbacks of the currently available tests for the detection of abnormalities in erythropoiesis $(9,10)$ have stimulated us to perform additional haemocytometric investigations. In particular, we have derived quantitative information from red blood cell size distribution histograms. Values established for the fractions of microcytes and macrocytes and values for the absolute distribution width at half peak height $\left(\mathrm{ADW}_{0.5}\right)$ are considered in this paper, together with the results of determinations reflecting the iron status.

\section{Subjects and Methods}

Blood samples were drawn in Venoject ${ }^{\circledR}$ vacuum tubes, anticoagulated with $\mathrm{K}_{3}$ EDTA (Terumo Europe N. V., 3030 Leuven, Belgium). Haemocytometric data, including the $\mathrm{ADW}_{0.5}$ value and the fractions of microcytes and macrocytes were determined by means of an Ortho ELT 800 WS $^{\circledR}$ Hematology Analyser according to the instructions in the operator reference manual (11).

\section{Absolute distribution width at half peak height}

The $\mathrm{ADW}_{0.5}$ values are measured from the histogram and expressed in femtolitres (fl) by using a conversion factor (12).

Procedure for determination of the fractions of microcytes and macrocytes

A mean red blood cell size distribution histogram for apparently healthy subjects has been calculated previously, in order to establish a threshold corresponding approximately to the $2.5^{\text {th }}$ and $97.5^{\text {th }}$ percentile, thereby arbitrarily limiting the fractions of microcytes and macrocytes. The threshold units are expressed in voltage channel numbers. In the reference curve the $2.5^{\text {th }}$ and $97.5^{\text {th }}$ percentile are found to correspond to channel number 21 and 35 respectively, representing red blood cell volumes of 65 and $108 \mathrm{fl}$. These channel numbers are assumed to be the limits of the fractions of microcytes and macrocytes respectively. The fraction of red blood cells below the lower threshold is considered to be the fraction of microcytes, whereas the upper threshold is used for the discrimination of the fraction of macrocytes. Once the discrimination limits have been established, the fractions of microcytes and macrocytes were calculated separately for each subject.

\section{Iron status}

Serum iron concentration and total iron binding capacity were determined by standard routine methods. Serum iron concentration is determined by using ferene as an indicator. Interference of copper is eliminated by addition of thiourea to the reagent (13). For determination of the iron binding capacity, excess ferric chloride is added to the serum sample in order to saturate the transferrin. Excess of free $\mathrm{Fe}^{3+}$-ions are removed by precipitation using magnesium hydroxy carbonate powder (14). The total iron binding capacity was determined by analysing the iron concentration in the supernatant. Serum ferritin concentration was assayed with the TANDEM-E-FER-kit (Hybritech, San Diego, CA 92126)), a two site enzymimmunometric assay. Vitamin $B_{12}$ and folate were determined with the Simultrac-kit (Becton \& Dickinson, Immunodiagnostics, Orangeburg, NY 10962).

\section{Reference group}

For establishing reference ranges, blood samples were collected from 72 apparently healthy males $(19-53$ years old) and 65 apparently healthy females $(20-45$ years old).

\section{Haemodialysis patients}

Twenty-two males and twenty-seven females with chronic renal insufficiency, under treatment by chronic intermittent haemodialysis for end-stage renal disease, were investigated. About $30 \%$ of this group incidentally received transfusions amounting to two units of red blood cells concentrates. The time frequency of blood transfusion varied between once every 4 weeks and once every 6 months. The ages of the subjects ranged from 35 to 83 years. Haemodialysis was performed two times a week for four hours. Blood samples were collected after finishing haemodialysis treatment.

\section{Results}

Haemocytometric values and results for serum concentrations reflecting iron, folate and vitamin $\mathrm{B}_{12}$ status for male and female subjects were processed separately, because sex-dependent variations may be present. The results for subjects receiving blood transfusions were similar to those for the other subjects. Ranges of haemocytometric values established for reference subjects and subjects treated by haemodialysis are shown in table 1 .

Individual haemocytometric results, viz. $\mathrm{Hb}$, red blood cell, $\mathrm{MCV}$ and $\mathrm{ADW}_{0.5}$ values, are depicted in figure 1. Limits of reference ranges are indicated in the figure. Results for male and female subjects are plotted separately. In all subjects except one, $\mathrm{Hb}^{1}$ ) and red blood cell concentrations are obviously decreased. $\mathrm{MCV}^{1}$ ) values are decreased in five males and five females. Increased $\mathrm{ADW}_{0.5}{ }^{1}$ ) values were observed in seven male subjects and three female subjects. Decreased $\mathrm{ADW}_{0.5}$ values are apparent in two male and four female subjects.

As shown in figure 2, nine male subjects and eight female subjects showed increased values for the fraction of microcytes. Normal MCV values were established in 4 of these males and 3 of these females. The fraction of macrocytes was increased in two males and in one female (fig. 3).

Serum concentrations of compounds reflecting the iron, folate and vitamin $B_{12}$ status are shown in table 2. Results of individual determinations reflecting the iron status are depicted in figure 4. Increased serum 

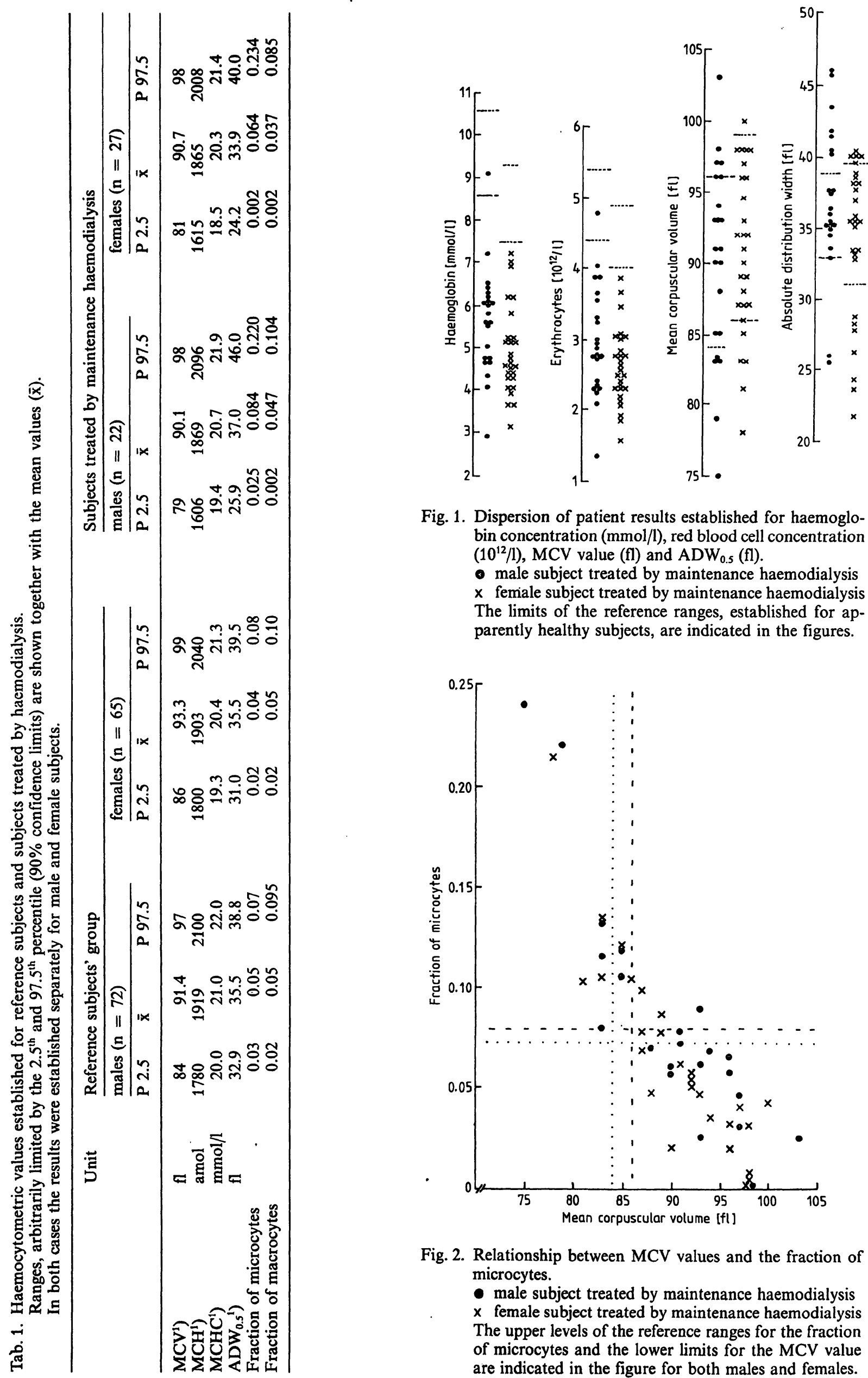

Fig. 1. Dispersion of patient results established for haemoglobin concentration $(\mathrm{mmol} / \mathrm{l})$, red blood cell concentration $\left(10^{12} / \mathrm{l}\right), \mathrm{MCV}$ value (fl) and $\mathrm{ADW}_{0.5}(\mathrm{fl})$.

- male subject treated by maintenance haemodialysis $x$ female subject treated by maintenance haemodialysis The limits of the reference ranges, established for apparently healthy subjects, are indicated in the figures.

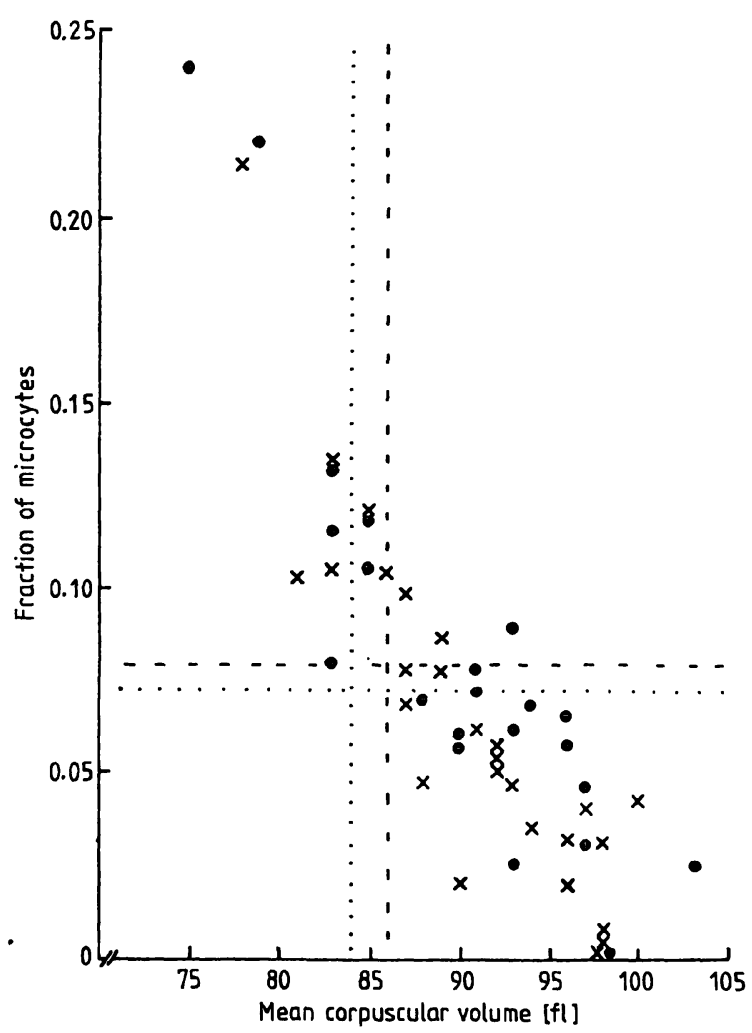

Fig. 2. Relationship between MCV values and the fraction of microcytes.

- male subject treated by maintenance haemodialysis $x$ female subject treated by maintenance haemodialysis The upper levels of the reference ranges for the fraction of microcytes and the lower limits for the $\mathrm{MCV}$ value are indicated in the figure for both males and females. 

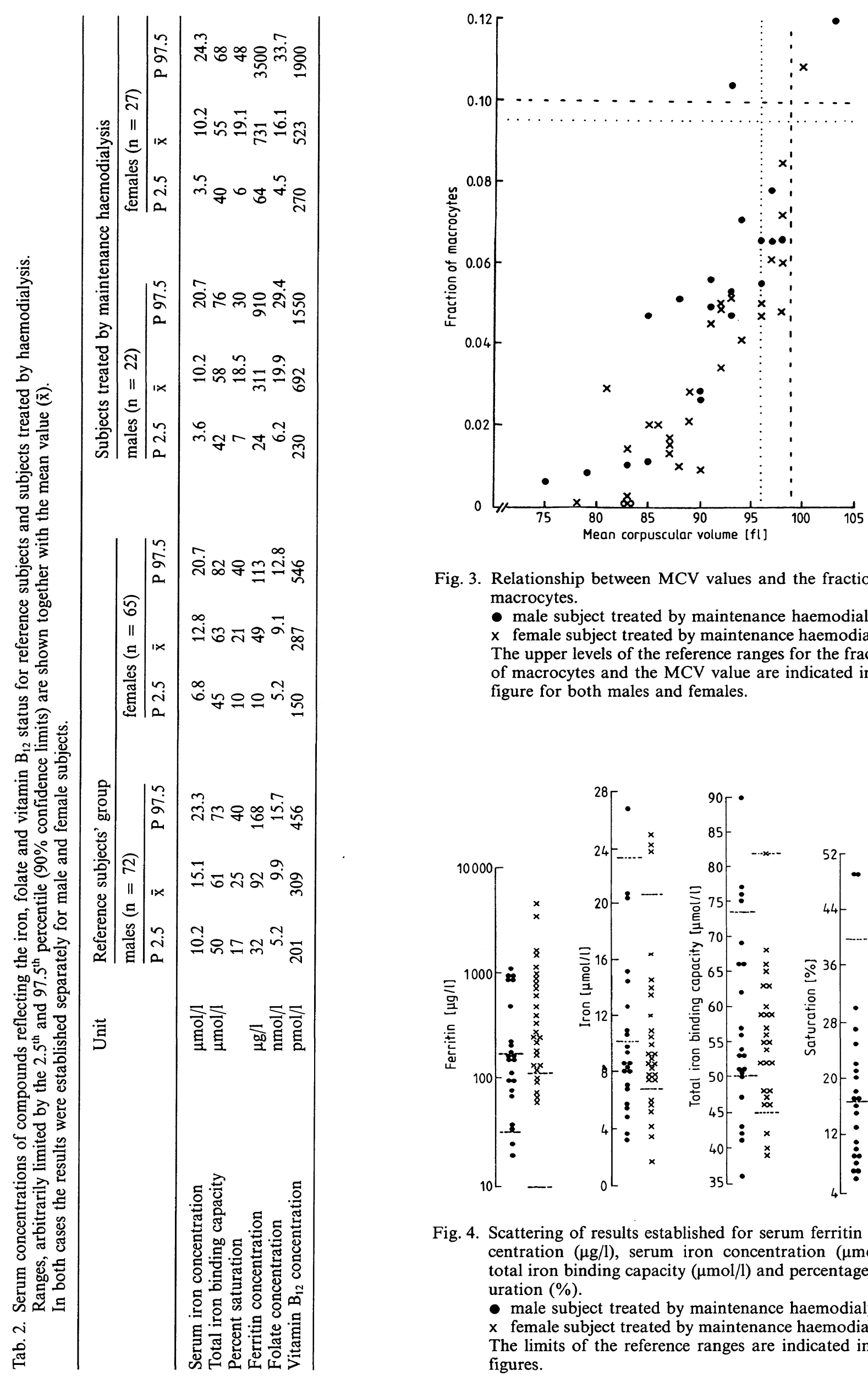

Fig. 3. Relationship between MCV values and the fraction of macrocytes.

- male subject treated by maintenance haemodialysis $x$ female subject treated by maintenance haemodialysis The upper levels of the reference ranges for the fraction of macrocytes and the MCV value are indicated in the figure for both males and females.

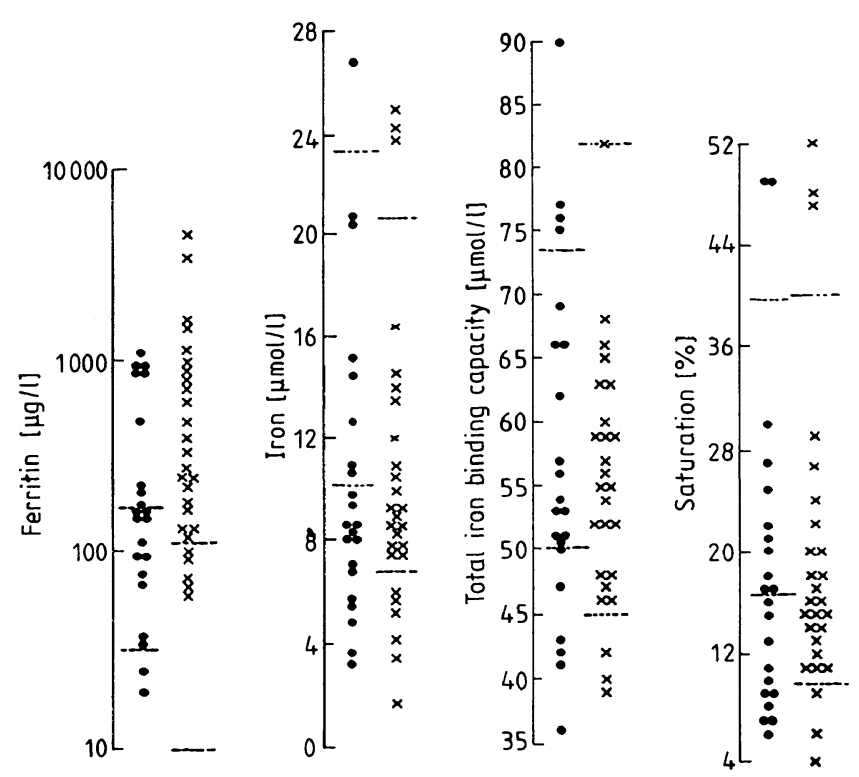

Fig. 4. Scattering of results established for serum ferritin concentration $(\mu \mathrm{g} / \mathrm{l})$, serum iron concentration $(\mu \mathrm{mol} / \mathrm{l})$, total iron binding capacity $(\mu \mathrm{mol} / \mathrm{l})$ and percentage saturation (\%).

- male subject treated by maintenance haemodialysis $x$ female subject treated by maintenance haemodialysis The limits of the reference ranges are indicated in the figures. 
ferritin concentrations are shown in nine (about $41 \%$ ) of the males and in 22 (about $80 \%$ ) of the females. Decreased serum iron concentrations are shown in fourteen males and six females. Total iron binding capacity values are increased in four males and borderline in one female subject. Iron saturation was decreased in a high number of subjects, viz. eleven males and three females.

\section{Discussion}

Haemocytometric determinations in subjects treated by haemodialysis were performed in order to obtain additional information with respect to disturbances in erythropoiesis. Blood samples for our study were collected after finishing the haemodialysis treatment. Experiments concerning the characteristics of the red blood cells in their prehaemodialysis environment were not performed.

In 19 out of 49 subjects abnormalities in red blood cells size distribution histograms were detected. Several conditions which may result in the production of increased amounts of microcytes or macrocytes are discussed below.

\section{Alterations in erythropoiesis}

\section{Red blood cell concentrations}

As shown in figure 1 concentrations of red blood cells are drastically reduced in subjects treated by maintenance haemodialysis. Similar results have been discussed elsewhere (15). Suppression of erythropoiesis may be due to accumulation of uraemic toxins, a decreased $\mathrm{pH}$, an increased concentration of inorganic phosphate or to a decreased concentration of erythropoietin (3). Erythropoiesis may further be decreased as a result of iron or folate deficiency.

\section{Degree of red blood cell volume dispersion}

Increased $\mathrm{ADW}_{0.5}$ values, demonstrating a red blood cell population with an increased degree of volume dispersion are observed in 11 subjects. Decreased $\mathrm{ADW}_{0.5}$ values are observed in 9 subjects. A decreased value for the red blood cell volume dispersion can be explained as follows. In less favourable conditions, red blood cells may acquire a membrane abnormality known as "burring", alternatively called "echinocytosis" (16). With respect to light scattering intensity, echinocytes resemble sphered red blood cells. It has been suggested elsewhere that preserved red blood cells show considerably less volume dispersion after ageing $(17,18)$ and after sphering $(19)$.

\section{The fraction of macrocytes}

As may be concluded from the results depicted in figure $3 \mathrm{MCV}$ values are increased in six subjects, whereas the fraction of macrocytes was increased in only three subjects. The size distributions show an increased degree of skew to the left, whereas the modal peak channel number is shifted to the right (own observation).

Neither decreased concentrations of folate in serum nor decreased vitamin $B_{12}$ concentrations could be detected in our subject group (tab. 2). Chronic disease in some cases combined with folate deficiency, sideroachresia or defects in the synthesis of the red blood cell membrane may yield possible explanations for the presence of macrocytes (20).

\section{The fraction of microcytes}

In seven subjects receiving maintenance haemodialysis, increased values were established for the fraction of microcytes, whereas MCV values were within the reference range. For the detection of several abnormalities, e.g. red blood cell fragmentation, poikilocytosis and minor changes in red blood cells volume dispersion, evaluation of the red blood cell size distribution histogram is supposed to be more reliable than the technician-dependent examination of the blood film (21).

\section{Iron stores}

\section{Iron deficiency}

In our study decreased serum iron concentrations were found in many subjects (fig. 4). Since intraindividual fluctuations may be relatively large the reliability of this analyte for diagnostic purposes is rather low.

Total iron binding capacity was found to be slightly increased in only 3 male subjects. In two of these the serum ferritin concentration was decreased. Iron deficiency may develop readily in subjects treated by chronic haemodialysis unless special precautions are taken. In subjects with chronic disease the serum ferritin concentration may be disproportionately increased in relation to marrow iron stores (10). Adequacy of iron stores as reflected by the serum ferritin concentrations may vary considerably according to the investigator and laboratory method used for the determination. In a study by $\operatorname{Docci}(7)$ haemodialysis patients with serum ferritin concentrations less than $65 \mu \mathrm{g} / \mathrm{l}$ showed a positive response to parenteral iron administration. However, a significant increase of $\mathrm{Hb}$ concentration was also detected in subjects with serum 
ferritin concentrations ranging from 65 to $160 \mu \mathrm{g} / \mathrm{l}$. Depletion of iron stores at an early stage might be clear from deviations in red blood cell size distribution histograms $(4,22)$.

\section{Iron overload}

When compared with the reference range, serum ferritin concentrations were increased in 31 subjects. In 6 of these subjects the serum ferritin concentration exceeded $1000 \mu \mathrm{g} / \mathrm{l}$. A markedly increased serum ferritin concentration may be a typical indication of early haemochromatosis.

\section{Aluminium intoxication}

Aluminium accumulation in patients undergoing haemodialysis may result, among other things, in the production of microcytic red blood cells (3). The mechanisms by which aluminium overload causes microcytic anaemia are unknown (2). This phenomenon was not further investigated in the present study.

\section{Conclusion}

In accordance with the results of a previous study (1), increased values for the fraction of microcytes are shown to be a more sensitive indicator for aberrations in red blood cell size distributions than $\mathrm{MCV}$ values. In the case of a normal red blood cell size distribution more extensive testing should be omitted, whereas in other cases aberrations in size distribution histograms may be a guideline for a more appropriate selection of patients for further investigations.

\section{References}

1. Bartels, P. C., Helleman, P. W. \& Soons, J. B. J. (1988) Evaluation of red blood cell size distribution histograms: the fraction of microcytes. Ann. Clin. Biochem. 25, 680687.

2. Abreo, K., Brown, S. T., Sella, M. \& Trapp, G. (1989) Application of an erythrocyte aluminium assay in the diagnosis of aluminium-associated microcytic anemia in patients undergoing dialysis and responses to deferoxamine therapy. J. Lab. Clin. Med. 113, 50-57.

3. Lewis, J. P. \& Meyers, F. J. (1984) The anemia of renal insufficiency. In: Laboratory Hematology (Koepke, J. A., ed.) Churchill Livingstone, New York, pp. 43-57.

4. Morgan, D. L. \& Peck, S. D. (1988) The use of red cell distribution width in the detection of iron deficiency in chronic hemodialysis patients. Am J. Clin. Pathol. 89, 513515.

5. Zanella, A., Gridelli, L., Berzuini, A., Colotti, M., Mozzi, M. T., Mozzi, F., Milano, S. \& Sirchia, G. (1989) Sensitivity and predictive value of serum ferritin and free erythrocyte protoporphyrin for iron deficiency. J. Lab. Clin. Med. 113, 73-78.

6. Ellis, D. (1979) Serum ferritin compared with other indices of iron status in children and teenagers undergoing maintenance hemodialysis. Clin. Chem. 25, 741-744.

7. Docci, D., Turci, F., Salvi, G., Cenciotti, L. \& Pistocchi, E. (1983) Serum ferritin in patients on maintenance hemodialysis. Nephron 34, $201-202$.

8. de la Serna, F. J., Gilsanz, F., Ruilope, L. M., Praga, M., Rodico, J. \& Alcazar, J. M. (1988) Improvement in the erythropoiesis of chronic haemodialysis patients with desferrioxamine. Lancet $i, 1009-1011$.

9. Thompson, W. G., Meola, T., Lipkin, M. \& Freedman, M. L. (1988) Red cell distribution width, mean corpuscular volume and transferrin saturation in the diagnosis of iron deficiency. Arch. Intern. Med. 148, 2128-2130.

10. Brown, R. D., Benfatto, J., Gibson, J. \& Kronenberg, H. (1988) Red cell ferritin and iron stores in patients with chronic disease. Eur. J. Haematol. 40, 136-141.

11. Operator Reference Manual Ortho ELT 800 Hematology Analyzer (laser-based), part no 168-0010-005. Ortho Diagnostic Systems Inc., Westwood, MA 02090.

12. Bartels, P. C., Helleman, P. W. \& Soons, J. B. J. (1989) Investigations on red cell size distribution histograms of normal male and female subjects. Scand. J. Clin. Lab. Invest. 49, 225-231.

13. van Oudheusden, A. P. M., Willink, J. H. \& van Buul, T (1983) Is de spectrofotometrische bepaling van ijzer in plasma of serum nog te verbeteren? Tijdschr. NVKC 8 , $17-18$.

14. Weissman, N. \& Pileggi, V. J. (1974) In: Clinical Chemistry. Principles and Technics, 2nd edn. (Henry, R. J., Cannon, D. C. \& Winkelman, J. W., eds.) Harper and Row Publishers, Hagerstown, pp. $681-695$.

15. Walle, A. J., Wong, G. Y., Clemons, G. K., Garcia, J. F. \& Niedermayer, W. (1987) Erythropoietin-hematocrit feedback circuit in the anemia of end-stage renal disease. Kidney International 31, 1205-1209.

16. Wagner, G. M., Chiu, T. Y., Yee, M. C. \& Lubin, B. H. (1986) Red cell vesiculation - a common membrane physiologic event. J. Lab. Clin. Med. 108, 305-324.

17. Greenwalt, T. J. \& Dumaswala, U. J. (1988) Effect of red cell age on vesiculation in vitro. Brit. J. Haematol. 68 , $465-467$.

18. Bartels, P. C. \& Roijers, A. F. M. (1988) Effects of ageing on preserved red blood cell populations as measured by light scattering. J. Clin. Chem. Clin. Biochem. 26, 29-33.

19. Bartels, P. C., Helleman, P. W., Roijers, A. F. M. \& Soons, J. B. J. (1988) Some effects on light scattering intensity and red blood cell size distribution histograms due to sphering. Ann. Clin. Biochem. 25, 673-679.

20. Minar, E., Zazgornik, J., Bayer, P. M., Lauschützer, H., Mengele, K. \& Marosi, L. (1984) Hämofiltrationsbehandlung unter besonderer Berücksichtigung der Folsäure- und Vitamin- $B_{12}$-serumkonzentrationen. Schweiz. Med. Wochenschr. 114, 48-53.

21. Bessman, J. D. (1988) Red blood cell fragmentation. Impaired detection and identification of causes. Am. J. Clin. Pathol. 90, 268-273.

22. Bessman, J. D., Gilmer, P. R. \& Gardner, F. H. (1983) Improved classification of anemias by $\mathrm{MCV}$ and RDW. Am. J. Clin. Pathol. 80, 242-246.

\section{P. C. Bartels}

Department of Clinical Chemistry

and Haematology

Medical Centre Alkmaar

van Everdingenstraat 18

NL-1814 HA Alkmaar 